\title{
A case for ethical frameworks to enhance mobile government implementation at South African municipalities
}

\begin{tabular}{|c|c|}
\hline $\begin{array}{l}\text { Authors: } \\
\text { Sandra Makw } \\
\text { Rufaro Garidz }\end{array}$ & $\begin{array}{l}\text { ember }^{1} \\
\text { rai }^{2} \text { (]) }\end{array}$ \\
\hline $\begin{array}{l}\text { Affiliations: } \\
\text { }{ }^{1} \text { Department } \\
\text { Development } \\
\text { Technology, Fa } \\
\text { Business Scien } \\
\text { Sisulu Univers } \\
\text { London, South }\end{array}$ & $\begin{array}{l}\text { f People } \\
\text { and } \\
\text { culty of } \\
\text { ces, Walter } \\
\text { ity, East } \\
\text { Africa }\end{array}$ \\
\hline $\begin{array}{l}\text { 2Department } \\
\text { Management, } \\
\text { Business Scien } \\
\text { Sisulu Univers } \\
\text { London, South }\end{array}$ & $\begin{array}{l}\text { Faculty of } \\
\text { ces, Walter } \\
\text { ity, East } \\
\text { Africa }\end{array}$ \\
\hline $\begin{array}{l}\text { Correspondin } \\
\text { Sandra Makw } \\
\text { smakwembere }\end{array}$ & $\begin{array}{l}\text { g author: } \\
\text { embere, } \\
\text { @wsu.ac.za }\end{array}$ \\
\hline $\begin{array}{l}\text { Dates: } \\
\text { Received: } 31 \mathrm{~J} \\
\text { Accepted: } 10 \mathrm{I} \\
\text { Published: } 19\end{array}$ & $\begin{array}{l}\text { an. } 2020 \\
\text { Mec. } 2020 \\
\text { Mar. } 2021\end{array}$ \\
\hline $\begin{array}{l}\text { How to cite th } \\
\text { Makwembere } \\
\text { A case for ethi } \\
\text { to enhance me } \\
\text { government in } \\
\text { at South Africa } \\
\text { municipalities. } \\
\text { res S Afr. } 2021 \\
\text { https://doi.org } \\
\text { td.v17i1.826 }\end{array}$ & $\begin{array}{l}\text { is article: } \\
\text { S, Garidzirai R. } \\
\text { cal frameworks } \\
\text { obile } \\
\text { nplementation } \\
\text { n } \\
\text { J transdiscipl } \\
\text {;17(1), a826. } \\
\text { y/10.4102/ }\end{array}$ \\
\hline $\begin{array}{l}\text { Copyright: } \\
\text { ( 2021. The A } \\
\text { Licensee: AOSI } \\
\text { is licensed und } \\
\text { Creative Comm } \\
\text { Attribution Lice }\end{array}$ & $\begin{array}{l}\text { uthors. } \\
\text { S. This work } \\
\text { ler the } \\
\text { nons } \\
\text { ense. }\end{array}$ \\
\hline Read online: & \\
\hline 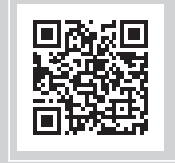 & $\begin{array}{l}\text { Scan this QR } \\
\text { code with your } \\
\text { smart phone or } \\
\text { mobile device } \\
\text { to read online. }\end{array}$ \\
\hline
\end{tabular}

Interest in mobile government (m-government) is growing globally. Mobile government refers to the use of wireless and mobile technologies to deliver services to citizens, businesses, employees and other government entities. Presently, technological advancements take place despite questions on whether the existing policy and regulatory frameworks are suitable to regulate the effects of m-government. With m-government, municipal operations take place in virtual spaces where the consequences of such operations are still largely unknown and the frameworks that are apt to minimise any long-term effects on society are yet to be defined. This conceptual article suggests that ethical frameworks should be encouraged as part of mobile government implementation in municipalities to encourage reflective municipal practices and to improve judgement and behaviour in m-government decision-making. It contributes to debates on approaches to comprehensively support and guide mobile government towards positive municipal service delivery outcomes.

Keywords: m-government; ethics; ethical frameworks; municipal service delivery; e-government; mobile technology.

\section{Introduction}

Globally, mobile government (m-government) is embraced by governments to modernise their diverse service delivery processes. Mobile-government can be viewed as an extension of electronic government (e-government). Elecronic-government involves the use of information and communication technologies (ICTs) to improve interactions between government and business (G2B), government and citizens (G2C), government and employees (G2E) and government and government (G2G). As an extension of e-government, m-government goes beyond these platforms to use mobile technologies. It serves a multitude of purposes. Like e-government, m-government has not only brought changes to service delivery channels but to public policy and practice. The scope of outcomes has been broad, from normative changes to policy adjustments to legislative reforms and to even shifts in political economies. ${ }^{1,2}$ Research has yet to fully grasp all the changes.

In South Africa, significant e-government and m-government-related changes have occurred over the years. Despite the fact that conceptualisations of technology are ambiguous, government has been under pressure to implement new technologies, often guided by private sector providers. Without assistance from the private sector, government innovation processes would risk moving at a slower pace and being less responsive because of bureaucratic government's internal processes and limited technology skills. As Weber ${ }^{3}$ argued, bureaucracy is the most efficient and rational way to structure organisations. Yet, in the present digital age it is a blight. Mobile government needs changes to organisational processes, amongst other things, so that they are more flexible and less hierarchical to match citizens' service needs.

Mobile-government at a local government level or local m-government can be distinguished from m-government at provincial or national levels. In view of local government's mandate, municipality systems and structures need to be apt to mould m-government for sustainable service delivery benefits. The evidence of what local m-government offers is still unfolding; hence, as local m-government is implemented, holistic approaches to dealing with risks should be sought. These should not focus on financial risks alone but include non-financial risks such as embedding beliefs, values and behaviours contrary to those that are expected in the public sector. Ethical frameworks can provide boundaries and structure to managing non-financial risks associated with m-government. Without them, the often covert and informal processes around 
local m-government will be left unidentified and unquestioned. A deeper understanding of the ethical dimensions of local e-government systems and practices is arguably necessary today. ${ }^{4,5,6,7}$ The laws that regulate the use of technology by government might exist, but they do not cater for important implicit issues related to individual judgements and behaviours. ${ }^{1,2}$ The lapses in the existing laws create incentives for behaviours that can compromise service delivery when m-government is implemented. Local m-government is shaping society and decisions made and responsibilities need to be interrogated. Concerns should not only be around the design of the m-government technologies. As organisations are social systems, concerns should be extended.

This article proposes that ethical frameworks are necessary for m-government implementation by municipalities to achieve positive service delivery outcomes. Technology misuse and negative social impacts need to be limited. What follows is a section with an overview of shifts in public service delivery paradigms from e-government paradigms to m-government paradigms. The paradigm shifts not only inform government work processes but also have implications for organisational beliefs, values and practices. The following section provides examples of m-government implementation experiences. Questions about the ethical adequacies are raised. The proceeding sections then present the kind of ethics frameworks that could be explored for local m-government. The article concludes with recommendations.

\section{Shifts in public service delivery paradigms}

The incorporation of modern technologies in government service delivery processes has placed governments on trajectories where a combination of administrative, fiscal and service delivery reform, amongst others have been witnessed. ${ }^{8,9,10}$ Notions of improved service delivery, reduced costs, responsive government, citizen-centric service delivery and flexible work arrangements are packaged with almost every project where governments introduce a new technology to its environments.

Government workplaces look quite different now compared with how they looked 30 years ago. Electronic government is a concept that is changing the face and experience of service delivery. $\mathrm{Ho}^{11}$ argued that governments introducing e-government move towards what can be referred to as an e-government service delivery paradigm. This paradigm emphasises coordinated network building, external collaboration and customer orientation. ${ }^{11}$ Table 1 illustrates the differences between the bureaucratic paradigm, which exists before e-government is introduced and the e-government paradigm conceptualised by Ho. ${ }^{11}$

The table points to the multilevel changes produced by the e-government paradigm. It transforms the organisational principles in government, which in turn provides different channels and experiences of service delivery. ${ }^{11}$ However, the e-government paradigm is not without limitations. As it focuses on the organisation, it reflects little of social factors. Organisations can be defined as social systems characterised by: (1) specific objective or function, (2) differentiated system structure and (3) links between system subsystems and the environment. $^{12}$ As Makwembere ${ }^{13}$ found, managing e-government implementation requires an understanding of organisations as forms of social systems. There are also social systems within the organisation itself and the organisation is part of social systems that extend its boundaries.

The m-government concept 'consists of the interactions between mobile state administrations, mobile citizens and mobile officials' (p. 14). ${ }^{14}$ The introduction of mobile technology has filled gaps in e-government. More people have mobile devices in comparison to those with internet access. Kushchu and Kuscu ${ }^{15}$ found mobile access to be growing as a daily part of life and that governments need to have more mobile activities. Unlike e-government which relies on the internet, m-government relies on mobile connectivity. It uses wireless technologies and mobile instruments such as mobile networks (e.g., broadband), mobile devices (e.g., feature phones, tablets) and related technologies (e.g., Short Message Service [SMS], voice calling).

Questions have been raised about whether m-government will replace e-government. Snellen and Thaens ${ }^{14}$ argued that the shift from e-government to m-government is a fundamental change. It has a potential to nurture a different set of relationships compared with e-government.

Whilst there are numerous studies on e-government maturity models, little has been written on m-government maturity models. Tozsa and Budai ${ }^{16}$ proposed four stages using the

TABLE 1: Shifting paradigms in public service delivery.

\begin{tabular}{lll}
\hline Variable & Bureaucratic paradigm & E-government paradigm \\
\hline Orientation & Production cost-efficiency & User satisfaction and control, flexibility \\
Process organisation & $\begin{array}{l}\text { Functional rationality, departmentalisation, vertical } \\
\text { hierarchy of control }\end{array}$ & Horizontal hierarchy, network organisation, information sharing \\
Management principle & Management by rule and mandate & Flexible management, interdepartmental team work with central coordination \\
Leadership style & Command and control & Facilitation and coordination, innovative entrepreneurship \\
Internal communication & Top-down, hierarchicsal & Multidirectional network with central coordination, direct communication \\
External communication & Centralised, formal, limited channels & Formal and informal, direct and fast feedback, multiple channels \\
Mode of service delivery & Documentary mode, and interpersonal interaction & Electronic exchange, non-face-to-face interaction (so far) \\
\hline Principles of service delivery & Standardisation, impartiality, equity & User-customisation, personalisation \\
\hline
\end{tabular}

Source: Ho ATK. Reinventing local governments and the e-government. Public Adm Rev. 2002;62(4):434-443. https://doi.org/10.1111/0033-3352.00197 
Gartner Group four stage model. The stages can be summarised as follows:

- Level 1 (Information): At this stage, communication is carried out using SMS. Users receive and respond to information through mobile network.

- Level 2 (Interaction): At this stage there is a collective transactional type of interaction, which occurs with prompt responses via SMS or Multimedia Messaging Service (MMS) technologies.

- Level 3 (Transactional): At this point, government offers services through different types of transactions, which are conducted through the use of mobile technologies over a mobile network.

- Level 4 (Transformation): Here, systems that have back-end functionality are implemented by the government and are used to process administrative services through mobile technology.

Fasanghari and Samimi ${ }^{17}$ offered a six-stage model based on a general view of technology, security and infrastructure. The stages can be summarised as follows:

- Stage 1 (E-government): During this stage citizens access government services with the infrastructures provided by e-government.

- Stage 2 (Migration): At this stage there is accessibility of information through using mobile devices.

- Stage 3 (Primary interaction): Here, citizens use their mobile devices to primarily interact with government websites and are able to search specific information using their mobile devices.

- Stage 4 (Full interaction): At this point citizens are able to interact and communicate with government on a full scale through mobile devices compared with stage 3 .

- Stage 5 (Transaction): At this stage, citizens are provided with an opportunity to conduct transactions based on the services that the government offers. Online interaction between citizens and government officials is more effective.

- Stage 6 (Ubiquity): At this final stage, the government makes services available in a ubiquitous way. Services or information are made available without any prior requests being made, for example, messages on weather forecasts.

The two models provide examples of how m-government development can be understood, but further model development is needed, especially for developing contexts with various socio-economic, socio-political and socio-cultural dynamics that differ from more developed contexts.

Whilst changes in paradigms in public administration as previously described may be argued to improve organisational structures or processes, one needs to ask: Does the m-government paradigms produce social systems for ethics to work? Are the changes to social systems associated with m-government taking place ethically? Are there ways to make ethical assessments to judge m-government implementation accordingly, for example, based on consequences versus compliance?

\section{Ethics and mobile government}

Ethics is deemed to be an important component of good governance. Traditional ethical scholars ignored technology because ethics was understood as concerned with human behaviour and technology was thought to be neutral. ${ }^{4}$ Four kinds or groupings of ethical theories can be described: consequence, duty, contract and character based. Consequence-based ethical theories hold that the consequences of actions and/or policies provide the measure against which moral decisions are evaluated. Hence, should a person be faced with choosing between action A or action B, the morally correct action will be the one that results in the most desirable outcomes. According to utilitarians, the outcomes for the majority in a particular society are of supreme consideration. They stress the 'social utility' of actions and policies by focusing on their consequences thereby emphasising the roles of acts and policies in yielding social good. Duty-based ethical theories hold that each person has an obligation or duty to his or her fellow human beings. Kant (1724-1804) held the premise that every person has the same moral worth and should not be treated as a means to an end thus he did not accept that morality could be grounded in the results of human actions. Ross ${ }^{18}$ believed that when two or more moral duties conflicted with each other, it was necessary to look at the individual circumstance to establish which duty would supersede the other. The individual circumstances would be important in determining the morally acceptable course of action and duty is a criterion for defining morality. Ross ${ }^{18}$ listed various prima facie duties people must follow. For example, honesty, meaning that every person has a prima facie duty, to be honest. Where two or more prima facie duties clash, Ross $^{18}$ held that a person could determine what his or her actual duty would be through a deliberate process of 'rational intuitionism'. Contract-based theories emphasise the existence of moral systems based on contractual agreements between individuals. Related to these are rights-based theories of morality, which recognise that all people have certain natural rights. Character-based ethical theories focus on criteria related to character acquisition and character development. To become an ethical person, one requires the development of virtues. ${ }^{13}$ By acquiring the right virtues, one could become a moral person.

Contemporary ethicists are increasingly paying attention to the effects of technology. For example, Johnson ${ }^{4}$ writes of anticipatory ethics. It refers to

(1) engagement with the ethical implications of a technology while the technology is still in the earliest stages of development and (2) engagement that is targeted to influence the development of the technology. (p. 64)

It is a fairly new approach that addresses ethical issues related to technology. As there is an absence of discussion on the ethics of local m-government and articulation of these matters where the implementation of projects is reported, anticipatory ethics offers an important outlook. 
Scholars have explored the ethical issues of emerging technologies, including in e-government.5,6 Mullen and Horner $^{7}$ found four categories of ethical issues with e-government: (1) those related to electronic environments, (2) those dependent on electronic environments, (3) those determined by electronic environment and (4) those unique to electronic environments. There appears to be little scholarly attention to ethical issues in m-government, more especially at a local government level.

Most municipalities have codes of ethics, but no ethical framework is transparently applied in the implementation of local m-government. An ethical framework, as part of a risk management strategy, would address ethical issues related to local m-government implementation. Local government is a channel for realising the aspirations of society as embodied in the constitution. Privacy, security, copyright and access tend to be emphasised in literature. Frameworks that enhance ethical focus can deal with questions such as 'is m-government harming people and in what way?'. Ethical responsibilities can be better outlined to ensure that m-government development processes ethically achieve desired service delivery outcomes. There are several possible impacts that could compromise ethical service delivery. Policy and legislative frameworks that make ethics an important feature of m-government development can protect important societal values, principles and beliefs. Already ethics in the public service has gained scholarly attention. What is missing is an extension of these debates to m-government implementation at local government level.

Ethical or unethical actions are predominantly 'a function of both the individual's characteristics and the environment in which he or she works' (p. 123). ${ }^{19}$ Understanding of why people make unethical decisions is incomplete, but choices can be planned ahead to reduce unethical actions. There are matters of ethics linked to the design process of m-government and the actual technologies created and matters of ethics after the municipality has taken the decision to roll out m-government technologies. The processes are related and the people involved in the processes function with a moral sense that needs to be guided to achieve positive collective public outcomes.

\section{Mobile government in South Africa}

South Africa is classified as a relatively new industrialised country and is making swift steps to m-government. The country has been performing well in the mobile fraternity as it is ranked fifth in the world. ${ }^{20}$ Statista ${ }^{20}$ reports that the number of people with cell phones exceeds the total population by $20 \%$. Simply put, most of South Africa's citizens have access to mobile phones because they are replacing desktops and laptops. This development has contributed to the acceptance of the m-government ideology. Proponents of the m-government systems argue that the m-government concept is convenient, saves time, minimises costs and can minimise corruption. ${ }^{21,22}$ However, despite the benefits attached to m-government systems, they are still at initial stages.
The driving force behind m-government implementation is the eight Batho Pele principles: courtesy, service standards, access, consultation, information, redress, openness and transparency and value for money. The Batho Pele principles emphasise placing citizens first when providing services. ${ }^{23}$ The principles have to be realised through the mobile technologies used. An increase in the number of citizens using mobile technology signals a willingness by citizens to use the m-government ideology to access government facilities. Given that most of the South Africans are living in extreme poverty, it is necessary for the South African government to invest more in responsible and ethical expansion of $\mathrm{m}$-government infrastructure.

The introduction of m-government has attracted scholarly attention, with a number of studies probing whether $\mathrm{m}$-government is a viable option in South Africa. Maumbe and Owei ${ }^{24}$ argued that introducing m-government system increases the unemployment rate in South Africa. This is because the mobile technology is deemed to perform the work that was supposed to be done by local residents. They further argued that m-government facilities are expensive to set-up. Despite their argument that m-government facilities are expensive and promote unemployment, Mehlomakulu ${ }^{25}$ propounded that it is the best way for a country to communicate with its citizens and improve service delivery. Similarly, Dlamini and Mpekoa $^{26}$ also argued that the m-government system improves service delivery. They emphasised that there is a need to come up with m-government mature models that are uniform and consistent. This would require that the government design universal applications on the mobile phones of citizens that allow them to, for example, pay bills and enquire about account balances. A recent survey by Dlamini and Mpekoa ${ }^{26}$ concluded that the m-government system improves the communication of a country with its citizens. However, there are looming questions on how m-government systems can be prioritised through ethically sound processes whilst building citizens' trust. There is a relationship between ethics and trust. As most citizens use mobile technology, the trust built through more ethical processes is crucial to m-government adoption.

Ogunleye, Van Belle and Fogill ${ }^{27}$ found that South African citizens are ready for m-government. The majority of the respondents in their study expressed interest in interacting with government using mobile services. This included paying their bills, requesting bill balances and making enquiries. The findings were linked to the high infiltration of mobile phones. Pertinent to note is that rural residents also expressed their willingness to communicate with the government although they do not have internet.

From the surveys and studies carried out on m-government in South Africa, it has proven to be well used to communicate with the country's citizens and eliminate red tape, thus improve service delivery in South Africa's government. The systems are advantageous at a local level as municipalities have a broad legislative mandate. Arguably, it is easier to 
manage the system as a micro system as compared with a macro system.

\section{Cases of mobile government at South African municipalities}

There are a number of examples of m-government implementation at a local government level. The Stellenbosch Municipality ${ }^{28}$ implemented the m-government system by launching the housing application to all the residents in the municipality. The main objective of the application is to allow the residents to apply for houses online and avoid enquiries queues. The municipality launched the application for residents to put their profile that will link them to all the financial services that finances houses. The application was designed so that it should not consume large amounts of data.

My Ekurhuleni App was put in motion by the Ekurhuleni local municipality. This project was also funded by Vodacom with the purpose of improving communication between the government and its citizens. In addition, the application was designed to report any service needed and to give suggestions on how the local government can improve service delivery. ${ }^{29}$

The Buffalo City Metropolitan Municipality launched a mobile application that permits citizens to pay bills, buy electricity and view their monthly statements. The objective of the implementation of the m-government system was to avoid long waiting periods and improve the service delivery. The application also gives residents the option to report any electric or plumbing faults. ${ }^{30}$

The City of Johannesburg Metropolitan Municipality has set in place a mobile system that makes municipal operations easier for the residents. The mobile system provides municipality statistics, residents' profiles, consumption, enables residents to check balances and pay bills online. ${ }^{31}$

Thinyane, Siebörger and Reynell ${ }^{32}$ conducted a study on the use of mobiles in the Makana local municipality targeting the Grahamstown community. The study used the MobiSam initiative and investigated the use of mobile phones in communicating with the local government. The results show that only $10 \%$ of the residents are without phones. In that $10 \%, 5 \%$ can have access to phones if need be. The respondents further state that they use cell phones to communicate with their leaders for service delivery. Despite using the mobile phones, the survey further revealed that the m-government system introduced the software via the playstore. The respondents also suggested that the application should include Xhosa and other local languages. ${ }^{32}$

\section{Local mobile government ethical dilemmas}

The m-government initiative has proven to improve service delivery in local municipalities. However, there are ethical dilemmas that the local government has faced in implementing this initiative. For instance, acquiring the m-government softwares and wireless network is a difficult task. The implementation of m-government means that the local government has to acquire all the licenses and resources for the initiative to be a success. Acquiring such licenses is costly and requires a huge capital outlay. ${ }^{33}$ This dilemma best suits the Free State local municipalities. The municipalities are finding it difficult to acquire the required licenses and resources for m-government. ${ }^{25}$

Another dilemma faced is the acceptance of the m-government initiative. There is a higher probability that the majority of the local resident's resist change from a traditional way of doing things to m-government initiative. ${ }^{34}$ For instance, the majority of Buffalo City Municipality residents are resisting change by not utilising the software that was introduced to address the improvement of service delivery. ${ }^{30}$ Rather, the majority of local residents prefer to queue at a local municipality for help. Such situations can lead to the rejection of the m-government in the long run. Thinyane, Siebörger and Reynell ${ }^{32}$ further highlight another barrier to $\mathrm{m}$-government in the Makana local municipality. The authors mention that m-government software is not compatible with the local residents' phones and that linking m-government software and residents' mobiles is not an easy task as it involves some legal intervention.

An additional ethical dilemma is the security of m-government systems. ${ }^{35}$ This includes information protection, personal information and email protection policies. It is sensitive to local residents for the local government to keep their private information. The residents fear that the information can be used by hackers, terrorists and hijackers to achieve their infractions. Therefore, government officials found it difficult to implement the m-government system fully. The Western Cape Province exemplifies this. The residents have accepted the m-government initiative but they fear that their privacy is at risk. ${ }^{36}$ An additional dilemma linked to the previous one is that local municipalities are faced with the ambiguous data protection law. ${ }^{26}$ It does not give the local municipalities the jurisdiction to allow the residents to sign documents online. This puts the local government at a compromising position to fully commit to the m-government initiative. On the other hand, some local residents hesitate to use the mobile services as they are fearful of fraudsters. Fraudsters often imitate municipalities on mobile platforms and try to get payment out of citizens. This has happened to many local municipalities. For example, a fraudster posing as the Executive Mayor of Polokwane municipality was asking for money to be deposited into their account in exchange for jobs and tenders. ${ }^{37}$ In Durban, an SMS fraudster circulated information to residents that their applications for a fake eThekwini Municipality learnership programme were successful and that they should pay a fee to secure their place. ${ }^{38}$ 


\section{A proposed ethical framework for local mobile government}

Mobile government is a subset of e-government. ${ }^{39}$ Ethical frameworks that underpin e-government ought to have a unique set of imperatives ${ }^{36}$ thus so do frameworks that underpin m-government. Kaisara and Panther ${ }^{40}$ recognised ethical issues for the e-government sector as privacy, e-inclusion, accessibility, property and accuracy. Local government embodies a variety of complex norms and values. Ethical values are not all-encompassing. Those which apply to local m-government implementation would need to be crafted.

The constitution and different pieces of legislation transfer ethical values in legal forms. Accountability, justice, respect and transparency are amongst the main ones. However, laws are not always based on ethics. Regarding m-government, without delving into the complexities of the relationship between ethics and law, one can ask what the nature of the ethics which should be applied for local m-government is, and whether present legislation adequately requires this.

A range of ethical values in municipalities become relevant when applying technology. Information and communication technology practitioners, for example, are trained to apply ethics in their design and provision of technology. They are trained to conduct their business ethically. However, municipal duty bearers, as clients with constitutional responsibilities, should think critically about what it means for them to implement technologies ethically. Specifically, what it means to implement m-government, a major government mandate, ethically.

Each municipality has distinct social contextual issues, such as culture and politics, which act as factors influencing local m-government implementation and should not be overlooked. Furthermore, internal and external actors, their interests and values, as well as the processes by which the m-government technologies are developed are important considerations. Presently, technologies are significantly changing society. As such, resolutions on the ethical values needed to guide local m-government implementation can assist with on-going reflexive decisionmaking. Sensitivity to ethical issues can limit unethical implementation. It should be noted that municipalities are not homogenous and neither are the people using m-government systems. The breadth of m-government means that in choosing to follow a more ethical path to local m-government implementation, decision makers can only hope to make the best possible decisions at a particular time. The multifaceted features of applications mean that outcomes can be achieved simultaneously but the impacts may not necessarily manifest simultaneously.

The territorial, demographic and jurisdictional basis of states have shifted with new technological applications. ${ }^{14}$ Public administrators need to proactively design and implement m-government systems whilst applying an ethical framework to minimise ethical dilemmas. Municipalities may apply a combination of ethical theories based on their perceived strengths.

An ethical framework needs assessment and evaluation aspects. The assessment aspect should include various reflections that can be made during decision-making on m-government. The evaluation aspect should comprise reflections to be made after actions are taken. These are considerations administrative decision makers and those responsible for municipal oversight can make. The following assessment questions can be included:

- What are the ethical and social aspects of the situation?

- What are all the available options?

- What factors impact the available options?

- What values do the potential actions fulfil? Do any values conflict? How will this be resolved?

- Do the actions optimise the common good or benefits of all recognised constituencies?

- What actions will achieve the most good at the time of intended implementation?

- What are the acceptable and unacceptable potential consequences of the actions?

- Do the actions respect the rights of individuals involved?

- Do the actions respect justice to and fairness for all parties involved?

- What are the potential institutional and non-institutional constraints?

- What knowledge and skill is needed to carry out the action? Is it available?

The following evaluation questions can be included:

- Have the processes and outcomes been handled in the best possible way?

- What might have been done differently?

Table 2 further proposes stages of an ethical framework that could be applied to m-government implementation. ${ }^{41}$ Furthermore, ethical attributes are emphasised along with a framework. For example, transparency and prudence. The attributes have what can be termed functional and symbolic benefits. ${ }^{42}$ Functional benefits relate to performance whilst symbolic benefit refers to extrinsic advantages. Whilst the concepts are used for marketing in the private sector, they are applicable in the public sector where service performance must ensure that needs are met through the consumption of public goods and extrinsic advantages must be realised, for example, human dignity. Role players (such as municipal staff, municipal management, political leadership, the Auditor General) and their roles can be outlined.

\section{Recommendations}

The following are recommendations that can support more ethical decision-making over local m-government and the development of ethical frameworks by municipalities and key stakeholders such as mobile network providers: 
TABLE 2: Stages of the ethical framework.

\begin{tabular}{|c|c|c|c|c|}
\hline Recognise the ethical issues & Get the facts & Evaluate alternative actions & Make a decision and test it & Act and reflect on the outcome \\
\hline $\begin{array}{l}\text { - Could this decision or situation } \\
\text { be damaging to someone or to } \\
\text { some group? Does this decision } \\
\text { involve a choice between a } \\
\text { good and bad alternative, or } \\
\text { perhaps between two 'goods' } \\
\text { or between two 'bads'? } \\
\text { - Is this issue about more than } \\
\text { what is legal or what is most } \\
\text { efficient? If so, how? }\end{array}$ & $\begin{array}{l}\text { - What are the relevant facts of } \\
\text { the case? What facts are not } \\
\text { known? Can I learn more } \\
\text { about the situation? Do I know } \\
\text { enough to make a decision? } \\
\text { - What individuals and groups } \\
\text { have an important stake in the } \\
\text { outcome? Are some concerns } \\
\text { more important? Why? } \\
\text { - What are the options for } \\
\text { acting? Have all the relevant } \\
\text { persons and groups been } \\
\text { consulted? Have I identified } \\
\text { creative options? }\end{array}$ & $\begin{array}{l}\text { - Evaluate the options by asking } \\
\text { the following questions: } \\
\text { - Which option will produce the } \\
\text { most good and do the least } \\
\text { harm? (The Utilitarian } \\
\text { Approach) } \\
\text { - Which option best respects } \\
\text { the rights of all who have a } \\
\text { stake? (The Rights Approach) } \\
\text { - Which option treats people } \\
\text { equally or proportionately? } \\
\text { (The Justice Approach) } \\
\text { - Which option best serves the } \\
\text { community as a whole, not } \\
\text { just some members? (The } \\
\text { Common Good Approach) } \\
\text { - Which option leads me to act } \\
\text { as the sort of person I want to } \\
\text { be? (The Virtue Approach) }\end{array}$ & $\begin{array}{l}\text { - Considering all these } \\
\text { approaches, which option best } \\
\text { addresses the situation? } \\
\text { - If I told someone I respect - or } \\
\text { told a television audience - } \\
\text { which option I have chosen, } \\
\text { what would they say? }\end{array}$ & $\begin{array}{l}\text { - How can my decision be } \\
\text { implemented with the greatest } \\
\text { care and attention to the } \\
\text { concerns of all stakeholders? } \\
\text { - How did my decision turn out } \\
\text { and what have I learned from } \\
\text { this specific situation? } \\
\text { - Have the processes and } \\
\text { outcomes been handled in the } \\
\text { best possible way? } \\
\text { - What might have been done } \\
\text { differently? }\end{array}$ \\
\hline
\end{tabular}

Source: Adapted from Markkula Centre for Applied ethics. A framework for ethical decision making [homepage on the Internet]. c2020 [cited 2020 Jan 3]. Available from: https://www.scu.edu/ ethics/ethics-resources/ethical-decision-making/a-framework-for-ethical-decision-making/

- develop a written ethical framework

- develop m-government ethical training that goes beyond the existing codes of ethics and codes of conduct to foster ethical culture in leadership over local m-government

- develop ethical indicators for local m-government implementation for accountability purposes

- conduct cost-benefit analysis of local m-government projects that include social costs and social savings

- improve local m-government monitoring and evaluation skills to deal with quantitative and qualitative measures

- develop social impact frameworks with local m-government implementation frameworks to minimise unethical implementation

- develop simple software applications that have simple functions and are simple to use

- use a bottom-up consultative approach to involve more stakeholders for better results

- pursue user-friendly frameworks relevant for and shared with all their stakeholders for improved adoption

- facilitate widespread m-government adoption by all municipalities, which prioritises regularly monitoring improvements to service delivery and accountability

\section{Conclusion}

The enduring socio-economic problems in society propel the South African government to use more advanced technologies to address these. As the available m-government technologies rapidly offer more capabilities, government laws and policymaking will not be able to respond in as quick a manner. A potential risk is that the effects of m-government related technological changes will continue to occur in obscure ways, thus proactive measures need to be taken. Policy and legislation cannot be expected to cover all the intricacies of m-government's evolution. Before m-government outpaces government's ability to regulate it, an exploration into what kinds of frameworks can improve future outcomes are worth pursuing. Ethical frameworks for m-government would be worth implementing to improve judgements, decisionmaking and safeguard society from irreversible degradation. The success of m-government is generally measured by the level of mobile technology use in municipalities.
However, looking to the near future, such a measure should be accompanied by an assessment of ethical steps institutionalised to achieve growth in technology use.

\section{Acknowledgements Competing interests}

The authors declare that they have no financial or personal relationships that may have inappropriately influenced them in writing this article.

\section{Authors' contributions}

S.M. and R.G. contributed equally to this work.

\section{Ethical considerations}

This article followed all ethical standards for a research without direct contact with human or animal subjects.

\section{Funding information}

This research received no specific grant from any funding agency in the public, commercial or not-for-profit sectors.

\section{Data availability}

Data sharing is not applicable to this article as no new data were created or analysed in this study.

\section{Disclaimer}

The views and opinions expressed in this article are those of the authors and do not necessarily reflect the official policy or position of any affiliated agency of the authors.

\section{References}

1. Rose J, Flak LS, Saebo O. Stakeholder theory for the e-government theory: Framing a value-oriented normative core. Gov Inf Q. 2018;35(3):362-374. https://doi. org/10.1016/j.giq.2018.06.005

2. Martins J, Fernandes B, Rohman I, Veiga L. The war on corruption: The role of electronic government. Electronic Government: 17th IFIP WG 8.5 International Conference; 2018; s.I., Austria; New York, NY: Springer.

3. Weber M. The theory of social and economic organisation (A.M. Henderson and T. Parsons translation). New York, NY: Oxford Press; 1947. 
4. Johnson DG. Software agents, anticipatory ethics and accountability. In: Marchant $\mathrm{GE}$, Allenby BR, Herkert JR, editors. The growing gap between emerging technologies and legal-ethical oversight: The pacing problem. New York, NY Springer, 2011; p. 61-76

5. Herkett JR. Ethical challenges of emerging technologies. In: Marchant GE, Allenby $\mathrm{BR}$, Herkert JR, editors. The growing gap between emerging technologies and legal-ethical oversight: The pacing problem. New York, NY: Springer, 2011 p. $35-44$

6. Roman AV. Framing the questions of e-government ethics: An organisational perspective. Am Rev Public Adm. 2013;45(2):216-236. https://doi.org/10.1177/ 0275074013485809

7. Mullen $\mathrm{H}, \mathrm{Horner} \mathrm{D}$. Ethical problems for e-government: An evaluative framework. EJEG. 2004;2(3):179-188.

8. Weerakkody V, Reddick CG. Public sector transformation through e-government: Experiences from Europe. New York, NY: Routledge; 2012.

9. Mohamed MZ, Xavier JA. Transforming public service delivery in Malaysia: The case of the implementation of e-government in local governments. Contemp Manag Res. 2016;10(1):39-57.

10. Chen Y, Dawes SS, Chen S. E-government support for administrative reform in China. Paper presented at: The 18th Annual International Conference on Digital Governance Research; 2017 June 07-09; Staten Island, NY: Association for Computing Machinery; 2017. pp. 329-335.

11. Ho ATK. Reinventing local governments and the e-government. Public Adm Rev. 2002;62(4):434-443. https://doi.org/10.1111/0033-3352.00197

12. Block M. Intra-organisational knowledge sharing: A holistic approach to the management of knowledge. Bremen: Europaeischer Hochschulverlag GmbH \& Co KG; 2013.

13. Makwembere S. Perceptions and experiences of G2E e-Government workplace restructuring: The cases of Buffalo City and City of Cape Town metropolitan municipalities [unpublished dissertation]. Grahamstown: Rhodes University; 2016.

14. Snellen I, Thaens M. From e-government to m-government: Towards new paradigm in public administration? [homepage on the Internet]. c2008 [cited 2020 Jan 20]. Available from: http://www.merit.unu.edu/training/ DEIP/2008 jordan/Tomasz\%20Janowski/UNPAN028992.pdf

15. Kushchu I, Kuscu MH. From E-government to M-government: Facing the inevitable [homepage on the Internet]. c2008 [cited 2020 Jan 20]. Available from: https:// citeseerx.ist.psu.edu/viewdoc/download?doi=10.1.1.113.2448\&rep=rep1\&type= pdf

16. Tozsa I, Budai B. M-government in Hungary. Paper presented at: The First European Mobile Government Conference; 2005 July 1-9; Brighton. London: Mobile Government Consortium International; 2005. pp. 414-424.

17. Fasanghari M, Samimi H. A novel framework for m-government implementation Paper presented at: International Conference on Future Computer and Communication; 2009 Apr 3-5; Kuala Lumpar, Malaysia. s.I.: IEEE; 2009. pp. 627-631.

18. Ross WD. The right and the good. Oxford: Clarendon Press; 1930.

19. Robbins SP. Organisational behaviour: Global and Southern African perspectives. Johannesburg: Pearson; 2001.

20. Mobile internet usage worldwide - Statistics \& facts [homepage on the Internet] c2019 [cited 2019 Dec 30]; Available from: https://www.statista.com/topics/779/ mobile-internet/

21. Wei Z, Gao X, Jia D, Yang Y. Research of mobile government based on multimodal platform with unified engine. Paper presented at: 2010 Internationa Conference on Intelligent Computing and Integrated Systems; 2010 Dec 3 Guilin, China. Piscataway: Institute of Electrical and Electronics Engineers; 2010 pp. 786-789.

22. Mtingwi JE. Mobile government readiness in Africa: The case of Malawi [unpublished dissertation]. Cape Town: University of Cape Town; 2012.

23. Department of Public Service and Administration. c2020 [updated 2021 Feb 23 cited 2020 Jan 3]. Available from: https://pmg.org.za/committee-meeting/ $28616 /$.
24. Maumbe MB, Owei V. Bringing M-government to South African citizens: Policy framework, delivery challenges and opportunities. E-services in a developing country: E-profile-based distribution and awareness generation approaches. country: E-profile-based distribution and awareness generation approaches. Dec 10-13. Wisconsin, United States of America. Atlanta, GA: Association for Dec 10-13; Wisconsin, United States
Information Systems; 2006. pp. 1-12.

25. Mehlomakulu S. The readiness for m-government in a South African provincial government [unpublished dissertation]. Stellenbosch: Stellenbosch University; 2014.

26. Dlamini DR, Mpekoa N. A review of m-government maturity models. Int J Multimed Image Process. 2018;8(1):389-397. https://doi.org/10.20533/ ijmip.2042.4647.2018.0048

27. Ogunleye OS, Van Belle JP, Fogwill, TA. Mobile government implementation for government service delivery in developing countries: A South Africa context [homepage on the Internet]. c2014 [cited 2020 Jan 10]. Available from: http:// worldcomp-proceedings.com/proc/p2014/EEE3548.pdf

28. Stellenbosch Municipality. c2019 [cited 2019 Dec 8]. Available from: https:// stellenbosch.gov.za/2019/08/26/stellenbosch-launches-housing-app/

29. Mzekandaba S. More municipalities go digital to boost service delivery [homepage on the Internet]. c2018 [cited 2020 Jan 10]. Available from: https://www.itweb. co.za/content/G98YdMLXONXMX2PD

30. Buffalo City Metropolitan Municipality [homepage on the Internet]. c2019. [cited 2020 Jan 08]. Available from: https://www.buffalocity.gov.za/app.php

31. City of Johannesburg Municipality. Integrated development plan 2019/20 review [homepage on the Internet]. c2018 [cited 2020 Jan 10]. Available from: https:// www.joburg.org.za/documents_/Pages/Key\%20Documents/Intergrated\%20 Development\%20Plan/Integrated-Development-Plan.aspx

32. Thinyane H, Siebörger I, Reynell E. Mobile phones for increasing public participation in local government. J Transdiscipl Res S Afr. 2015;10(3):241-259.

33. Manoharan AP, Ingrams A. Conceptualising e-government from local government perspectives. State Local Gov Rev. 2018;50(1):56-66. https://doi.org/ $10.1177 / 0160323 \times 18763964$

34. Al-Hadidi A, Rezgui Y. Adoption and diffusion of m-government: Challenges and future directions for research. Working Conference on Virtual Enterprises; 2010 Oct 11-13; Etienne, France; Berlin: Springer; 2010. pp. 88-94.

35. Royakkers L, Timmer J, Kool L, Van Est R. Societal and ethical issues of digitisation. Ethics Inf Technol. 2018;20(2):127-142. https://doi.org/10.1007/s10676-018-9452-x

36. Western Cape Government. Annual Report 2018-2019 [homepage on the Internet]. c2019 [cited 2020 Jan 03]. Available from: https://www.westerncape. gov.za/assets/departments/health/annual_report_2019.pdf

37. City of Polokwane. Public is urged to be alert of the SMS scam circulating [homepage on the Internet]. c2020 [cited 2020 Dec 12]. Available from: https:// polokwane.gov.za/SPX $\% 20$ News $\% 20$ Article/Public $\% 20$ is $\% 20$ urged $\% 20$ to $\% 20$ be $\% 20$ alert $\% 20$ of $\% 20$ the $\% 20$ sms $\% 20$ scam $\% 20$ circulating.aspx

38. EThekwini newsflash: Artisan learner ship programme SMS is a scam [homepage on the Internet]. c2020 [cited 2020 Dec 12]. Available from: http://www.durban. gov.za/Resource_Centre/Press_Releases/Pages/Artisan-Leanership-ProgrammeSMS-is-a-Scam.aspx

39. Sinnari $\mathrm{D}$, Al-Nuaim $\mathrm{H}$. The use of mobile technology for citizen e-participation. In: Benlamri R, editor. Networked digital technologies. NDT 2012. Berlin: Springer, 2012; p. 294.

40. Kaisara G, Panther S. Relevance of ethics in e-government: An analysis of developments in the WWW era. Paper presented at: 6th International Conference developments in the WWW era. Paper presented at: 6th International Conference on e-government; 2006. Sep 30-Oct 1;

41. Markkula Centre for Applied ethics. A framework for ethical decision making [homepage on the Internet]. c2020 [cited 2020 Jan 3]. Available from: https:// www.scu.edu/ethics/ethics-resources/ethical-decision-making/a-framework-forwww.scu.edu/ethics/ethics-

42. Bodur HO, Gao T, Grohmann B. The ethical attribute stigma: Understanding when ethical attributes improve consumer responses to product evaluations. J Bus Ethics. 2014;122:167-177. https://doi.org/10.1007/s10551-013-1764-5 